\title{
Disease-related conflicts in mammal conservation
}

\author{
Christian Gortázar ${ }^{\mathrm{A}}$, Ezio Ferroglio ${ }^{\mathrm{B}}$, Catherine E. Lutton ${ }^{\mathrm{A}, \mathrm{C}}$ and Pelayo Acevedo ${ }^{\mathrm{D}, \mathrm{E}}$ \\ A IREC Wildlife Research Institute (CSIC-UCLM-JCCM), Ronda de Toledo s.n., 13071 Ciudad Real, Spain. \\ B Dipartimento di Produzioni Animali, Epidemiologia ed Ecologia, Università di Torino, Via Leonardo Da Vinci 44, \\ 10095 Grugliasco (TO), Italy. \\ ${ }^{C}$ Environment Department, University of York, Heslington, York, North Yorkshire, YO10 5DD, United Kingdom. \\ Diogeography, Diversity, and Conservation Research Team, Department of Animal Biology, Faculty of Sciences, \\ University of Malaga, E-29071 Málaga, Spain. \\ ECorresponding author. Email: pacevedo@uma.es or pacevedo@irec.csic.es
}

\begin{abstract}
Diseases pose a major direct or indirect threat to the conservation of endangered species, and can be a source of conflict among the stakeholders in conservation efforts. We aim to provide examples of disease-related conflicts in conservation, and information that can be used to identify means to reduce existing conflicts and avoid potential new ones. After introducing how diseases can affect conservation efforts, we have provided examples of different types of diseaserelated conflicts, including (1) those related to the movements of hosts, vectors and pathogens, (2) those linked to cats and dogs living in contact with wild carnivores, (3) those related to ungulate overabundance and (4) those related to carrion and hunting remains. We then discuss the management options available to mitigate these situations and resolve the conflicts surrounding them. Disease-related conflicts can affect conservation in several different ways. Whereas it is clear that diseases must be considered in any recovery plan for endangered species, as well as for sympatric and related abundant species such as relevant prey, it is also important to foresee and mitigate any eventual disease-related conflicts. Where conflicts have arisen, identifying the cultural carrying capacity for a disease or disease host species will help identify management strategies. It is important to quantify the risks for stakeholders and educate them about possible solutions. Multidisciplinary research teams that communicate their work to stakeholders should help resolve conflicts. Management options will not only depend on the status of the endangered host species and the epidemiology of the diseases considered, but also on the levels of existing conflict. Conservation strategies affected by diseases should explicitly include efforts to educate and inform all stakeholders as required throughout the process, and tackle any conflicts that arise.
\end{abstract}

Additional keywords: conflict mitigation, conflict resolution, endangered species, wildlife diseases, wildlife management.

\section{Introduction}

Diseases can greatly affect local species populations by causing temporary or permanent declines in productivity or abundance, leading, in some circumstances, to conflicts in mammal conservation (e.g. Rushton et al. 2006). Furthermore, pathogens can interact with other driving factors, such as habitat loss, climate change, overexploitation, invasive species or environmental pollution to contribute to local or global extinctions (Smith et al. 2009). The effect of diseases on the conservation status of wildlife can be direct, affecting an emblematic or endangered species, or indirect, affecting the food (prey species) for such species. Endangered species tend to have small or isolated populations that are particularly susceptible to disease. Abundant species may also be vulnerable in situations where an emerging disease to which they have no resistance affects them or a keystone predator or prey species.

Classic examples of direct disease-related conservation conflicts include the role of viral diseases in the conservation effort of the black-footed ferret (Mustela nigripes) in North America (Thorne and Williams 1988), and in the conservation of endangered canids such as the Ethiopian wolf(Canis simensis) and the African wild dog (Lycaon pictus) in East Africa (e.g. Knobel et al. 2008). Examples of indirect effects of diseases include the depletion of prairie dog (Cynomys ludovicianus) colonies as a result of plague (Hanson et al. 2007), with adverse effects on the black-footed ferret, or the consequences for the Iberian lynx (Lynx pardinus), the most endangered cat species in the world (von Arx and BreitenmoserWursten 2008), and the decline of many other endangered predators of the European rabbit (Oryctolagus cuniculus) as a result of viral diseases (Delibes-Mateos et al. 2007).

Other examples of disease-related conflicts in mammal conservation include the debate on the culling of the badger (Meles meles) in the UK. In the UK, badgers are a protected species, but have been identified as a wildlife reservoir for bovine tuberculosis (bTB), contributing to the maintenance of the disease in the population of cattle livestock (e.g. Donnelly et al. 2003). As a result, farmers are keen to pursue culling strategies to remove badgers from their land. Proactive badger removal in Ireland reduced the number of herd restrictions that were used to 
control bTB in cattle in culled areas (Griffin et al. 2005). The debate therefore continues, despite evidence that culling may increase the overall potential for transmission of bTB from badgers to cattle (Woodroffe et al. 2006; Pope et al. 2007), that it is unlikely to be cost effective (Bennett et al. 2005; Jenkins et al. 2010) or sustainable over time (Griffin et al. 2005), and that the general public are strongly opposed to culling (Bennett and Willis 2008). In a similar way, there has also been conflict over the control of fox rabies because of the increasing fox-population trends in central Europe (Vos 2003).

In all of these situations conflicts arise between stakeholders over how the situation should be resolved, and this can slow the process of introducing a successful conservation strategy. Conflicts can arise between various stakeholders, such as veterinarians, hunters and/or conservationists. So, whereas the veterinary authorities hope to maintain public and livestock health, hunters want the preservation of quality hunting areas and game, whereas game producers need management freedom to provide this and maintain profitability, and may therefore be less concerned about low levels of disease. In many places, the general public have increasingly anti-hunting views and are concerned about animal welfare. In this context, conservationists, although concentrating on biodiversity conservation, need to be mindful of all of these viewpoints.

Conservation initiatives often struggle to get sufficient funding, and conflicts can drive up the costs of a project. Rondinini and Boitani (2007) showed that for conservation of large carnivores, choosing a conservation strategy that avoids areas of conflict could be as much as four times less expensive than in areas where there is conflict over management. However, conflicts cannot always be avoided and a proactive approach to prevention and mitigation is necessary. In the present review, we first describe examples of the types of disease-related conservation conflicts that may occur, before discussing management options to mitigate and resolve these problems.

\section{Examples of disease-related conservation conflicts}

Conservation conflicts and movements of hosts, vectors and pathogens

Human-mediated introductions dramatically increase the contact rates between hosts, vectors and pathogens, increasing both novel contacts among species and previously existing ones. In addition to the ecological consequences that may directly affect conservation efforts (Gurevitch and Padilla 2004), introductions may cause new disease conflicts, because the introduced species may carry or spread diseases that present a risk to native fauna, livestock and humans (e.g. Rushton et al. 2006). One such example is the case of European rabbit and its introduction from its native range in Iberia to other countries around the world. Rabbits have notably declined within their native distribution (Moreno et al. 2007; Williams et al. 2007) as a result of the appearance of myxomatosis and rabbit hemorrhagic disease (Fig. 1). However, in regions where they have been introduced, most notably Australia and New Zealand, numbers have generally increased to the point where they have become a pest species. In this situation, applied research for rabbit management has two opposite goals, namely conservation in the original range, and population-control measures in those countries where the species has become a pest. Both goals

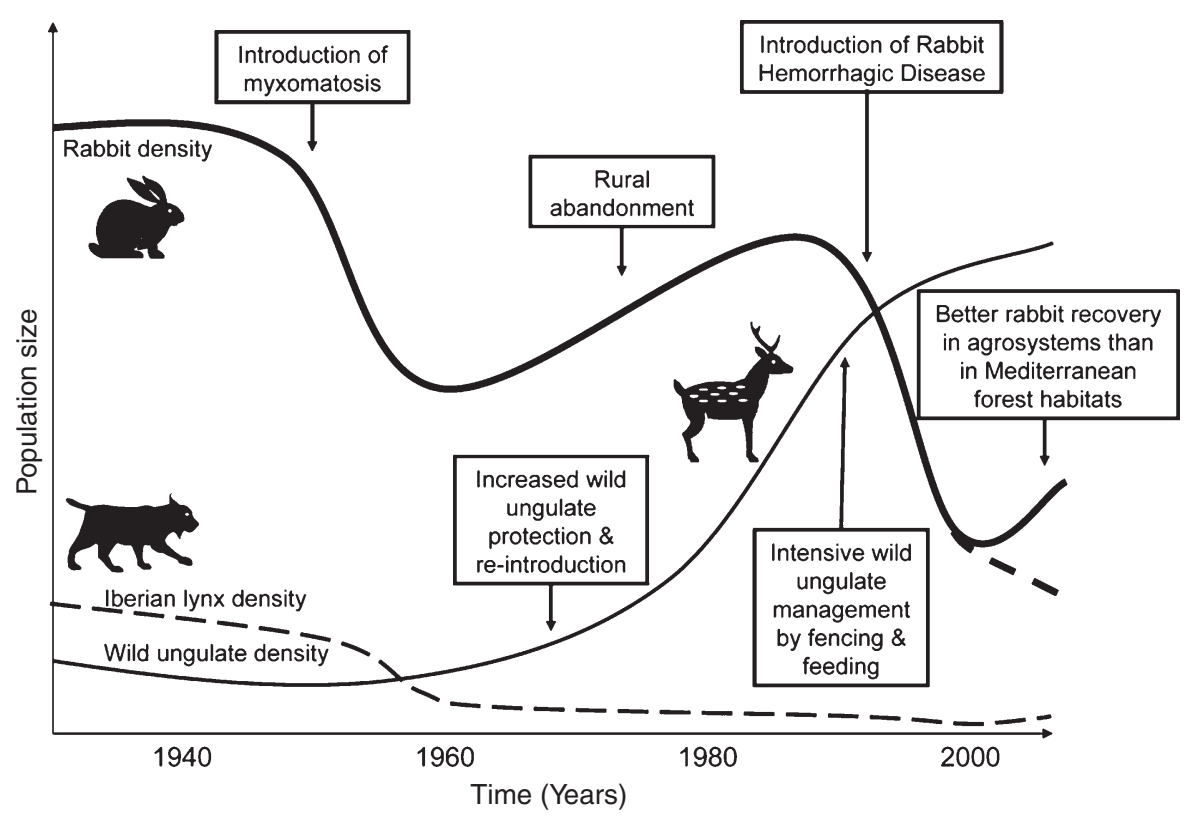

Fig. 1. Schematic representation of European rabbit and wild-ungulate (deer and wild boar) population trends in the Iberian peninsula, and key factors determining changes during the 20th century. After the second rabbit decline, many landowners switched from small-game (bird and small mammal) management to largegame (deer and wild boar) management. This further contributed to rabbit decline in the best-preserved Mediterranean woodland habitats, where they were an important source of prey for species that are now of conservation concern. 
have important conservation implications. In Iberia, the decline in rabbit numbers has led to cascading effects on their predators, including the Iberian lynx (Real et al. 2009) and the imperial eagle (Aquila adalberti), and serious ecological and economic consequences (Delibes-Mateos et al. 2008). Outside their native range, the presence of rabbits tends to alter the composition and abundance of native flora and fauna, for example, by contributing to the extinction of many marsupial species in Australia (Fisher et al. 2003; Lees and Bell 2008).

The peculiarity of this case is that one management objective could be easily met with the use of a recombinant vaccine (based on an attenuated but transmissible myxomavirus genetically modified to provide immunity), which has been developed to protect against myxomatosis and rabbit haemorrhagic disease. The key concept of this vaccine is that it is transmissible by contact between rabbits, so only a few rabbits need to be vaccinated initially to achieve immunisation of the greater population (Bárcena et al. 2000). The same concept of horizontal transmission was considered as the basis for developing another vaccine (a genetically modified virus) for rabbit-population control, reducing fertility through transmissible immunocontraception (Tyndale-Biscoe 1991; but see Henzell et al. 2008). Although both vaccines could be valuable in managing rabbits in the countries where they were developed, the conservation conflict is that they may cause an entirely unwanted and dramatic effect in another country because the history of rabbit viruses shows clearly their ability to spread globally (Fenner and Fantini 1999; Angulo and Cooke 2002; Saunders et al. 2010). A wealth of biological tools is available to manage rabbit populations. However, their application is unlikely, partly because of the potential conflicts that would arise if the wrong vaccine were used in the opposing situations, i.e. rabbit as keystone species $v$. rabbit as pest species. Moreover, it is not realistic to think that preventing further movement of rabbits between countries might allow for the use of these vaccines Therefore, efforts need to be concentrated on developing alternative management tools that account for a range of stakeholder objectives.

Another ongoing example of human-mediated introductions that produce conflicts is pet trade. Daily, wild animals are moved through trading centres where they are in contact with many other species, potentially exchanging pathogens before being purchased. In some cases, pets may escape or be released into the wild. This dramatically increases the movement and potential cross-species transmission of pathogens between pets and wild or domestic animals, causing conflicts between different and sometimes opposing interests. Pet owners want companionship and enjoyment, pet traders have economic interests and conservationists are interested in the success of wildlife conservation efforts. Raccoons (Procyon lotor), for example, are becoming increasingly popular as pets in Europe. This is resulting in numerous intentional releases or escapes into the wild, with potential adverse effects on conservation and the risk of introducing diseases or parasites (e.g. Woodford and Rossiter 1993). One intestinal nematode of raccoons that is highly pathogenic in intermediate hosts is Baylisascaris procyonis. It is hypothesised to have caused or contributed to the extirpation of the Allegheny woodrat (Neotoma magister) from the northern parts of its range in North America. Experimental evidence strongly suggests a negative effect of exposure to B. procyonis eggs on Allegheny woodrat survival (Logiudice 2003), and might cause similar harm to small mammal species in Europe. Raccoon dogs (Nyctereutes procyonoides) have also spread into new habitats in Europe after accidental release of animals raised for fur trade, and are known to be transmitting rabies, as well as acting as hosts to many parasite species (Gylys et al. 1998). To reduce the spread of diseases caused by the movement of animals, the public should be educated about the risks associated with wildlife and exotic pet trades; and proper surveillance systems should be implemented (Artois et al. 2009).

Conflicts may also occur in relation to the movement of animals to meet conservation objectives. In Spain, opposite views on the relevance of Cytauxzoon (a protozoal disease that can also affect domestic cats) in Iberian lynx complicated the incorporation of new animals into the captive breeding program. The scientific community debated whether to move animals from a potential source population to the captive breeding facility or not, because this potential pathogen had been detected in the source population but not in the captive animals (Millán et al. 2007). Although caution is always important, it is likely that the delay caused by this debate negatively affected the captive breeding effort, and this highlights the need for scientific understanding of the diseases causing conflict.

\section{Conservation conflicts in domestic pet ownership}

One largely unresolved conflict is the control of dogs and cats in wildlife areas. The case of feline leukemia virus (FeLV) transmission from cats to Iberian lynx in the Doñana National Park in Spain is a good example. During spring 2007, a FeLV (a retrovirus that mainly affects domestic cats and is transmitted by direct contact) outbreak occurred in the Doñana lynx population, one of only two remaining stable populations of this species (Rodríguez 2007; López et al. 2009), with only 26 lynx individuals estimated to be remaining in 2003 (Garrote et al. in press). This situation started a debate on the convenience of controlling cats and dogs in Doñana and in the surrounding villages. However, pet owners were reluctant to accept any intervention and even within the National Park, which is of high economic and social importance to the area, do not support the stray-cat and -dog control measures. The conditions therefore exist for new outbreaks of this and other diseases, such as distemper viruses (Roelke et al. 2008; Millán et al. 2009). Similar concerns have been expressed regarding diseases shared between the endangered Florida puma (Puma concolor) and domestic cats in North America (Cunningham et al. 2008). In these situations, it is important to educate the public regarding the risks that stray domestic animals may represent for endangered ones. Efforts to improve the keeping and the health of carnivore pets will also be rewarding. Regarding uncontrolled dogs in developing countries, other conflicts may arise. Instead of dog-control, pet-vaccination strategies may be required to reduce the risks of viral epidemics among endangered wild carnivores (Roelke-Parker et al. 1996; Haydon et al. 2006). Positive strategies such as improving efforts to maintain the health of pet and stray carnivores that account for stakeholders' wishes will encourage engagement. 


\section{Conservation conflicts resulting from ungulate overabundance}

According to Caughley (1981), overabundance of a given wildlife species occurs when (1) this affects human life or well being, (2) it affects the fitness of the overabundant species, (3) it reduces the density of species with an economic or aesthetic value or (4) it causes dysfunctions in the ecosystem (see also Côté et al. 2004). In this context, several studies already highlighted the relationship between overabundance and disease (reviewed by Gortázar et al. 2006). Diseases maintained among overabundant wildlife populations in protected areas or managed for hunting purposes can easily result in a conflict of interests among land owners, authorities, hunters, conservationists and livestock breeders when the disease spreads (Gortázar et al. 2006, 2008). The history of bTB in southern Spain is just one of several possible examples. Here, wild ungulates are important games species, and have been disproportionately favoured and conserved at the same time as their predators, e.g. the European wolf (Canis lupus), are experiencing a population decline (Grilo et al. 2002; Gortázar et al. 2006). High levels of bTB prevalence have now been recorded in wild ungulates in central and southern Spain, maintaining a multi-host system of bTB transmission that more than likely involves the livestock populations (Gortázar et al. 2008). This situation is further complicated by the likely addition of new stakeholders and management objectives to the area. For example, there is a potential conflict between the pig industry, which is increasingly prioritising welfare and environmentally friendly but biosafe open-air pig production, and hunters maintaining profitable densities of Eurasian wild boar
(Sus scrofa) without disease control (Ruiz-Fons et al. 2008). It is not unlikely that similar situations could arise in the future in other regions, with an increasing disease gradient between livestock and wildlife (Fig. 2). Disease transmission between wildlife and livestock can undermine conservation efforts if wildlife is seen as the source of a disease affecting livestock or human health. Stakeholder education and involvement may mitigate some of these fears and also increase the likelihood of being able to mitigate potential future conflicts.

\section{Conservation conflicts related to carrion and hunting remains}

A different kind of conflict exists regarding the conservation of carrion-consuming species. In Europe, several endangered carnivores such as the Eurasian brown bear (Ursus arctos arctos) or European wolf benefit from access to livestock or wild ungulate remains (e.g. hunting gutpiles). Moreover, a long list of endangered birds of prey also depends on this resource. However, in the past few decades, new legislation for the control of spongiform encephalopathies in domestic ruminants has significantly lowered the available carrion for birds and other carrion consumers (e.g. Donázar et al. 2009). This creates a conflict between public-health and animal-health interests on one hand, and conservation on the other hand. The limitations regarding carcass availability for wildlife are less strict for nonruminant livestock such as pigs and poultry. However, high levels of antibiotics and other medicines are sometimes used during farming these livestock. These can eventually also pose a risk for the conservation of threatened species, and generate conflicts

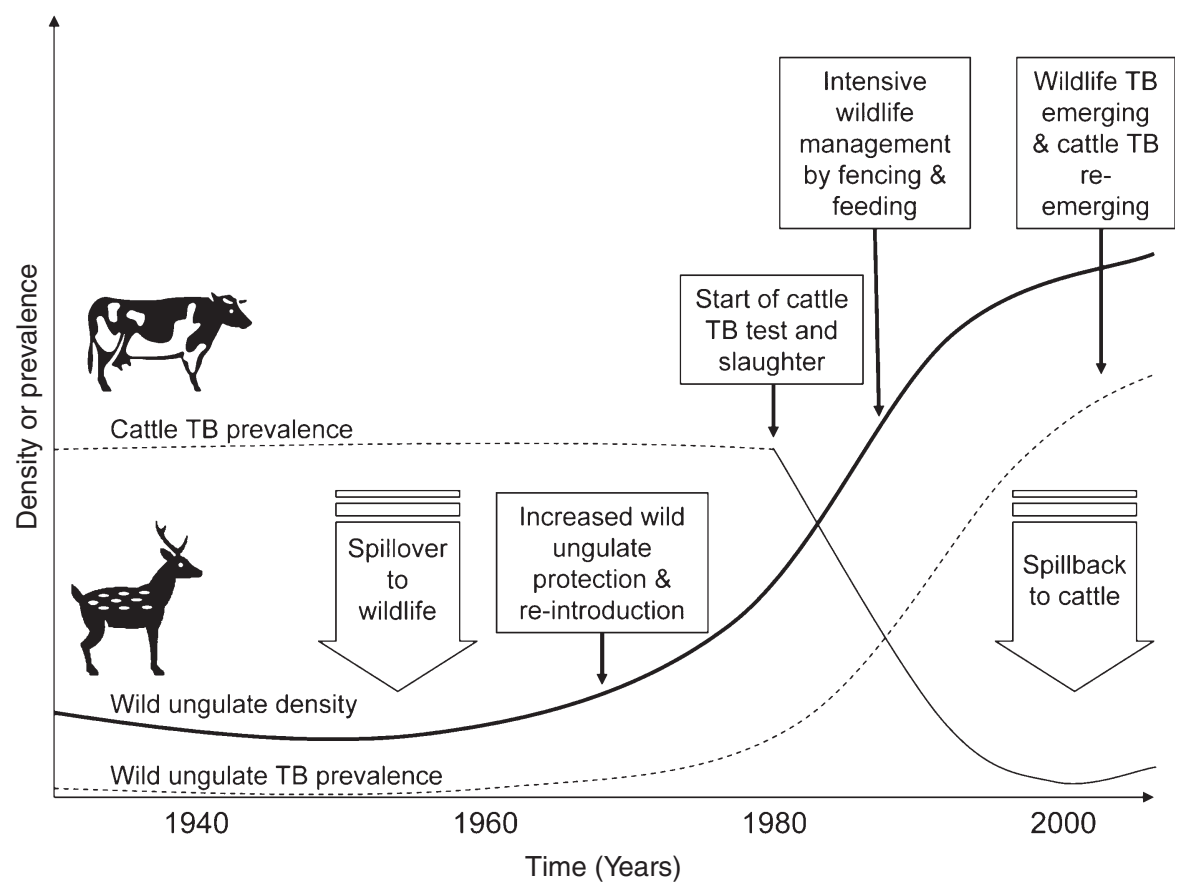

Fig. 2. Overabundant wild ungulates and bovine tuberculosis (bTB) in southern Spain. The solid line represents the demographic explosion of wild ungulates, mainly Eurasian wild boar (Sus scrofa) and red deer (Cervus elaphus) in southern Spain. Cattle bTB prevalence has dropped since the test and slaughter program started, whereas wildlife bTB is probably increasing in parallel to wild-ungulate densities, causing direct conservation concerns (e.g. Iberian lynx) and possible indirect effects on the preservation of wildlife habitats. 
between the livestock industry and conservationists (Taggart et al. 2007; Lemus et al. 2008). One almost natural source of carrion is hunter-harvested wild-ungulate carcasses or carcass remains (Gortázar et al. 2008; Mateo-Tomás and Olea 2010). This is a significant source of food for carrion consumers in areas with abundant wild ungulates. However, research is showing that hunter-harvested wild-ungulate remains contain high levels of lead that can affect birds feeding on them (Reglero et al. 2008). Furthermore, as overabundant wild-ungulate populations often maintain shared diseases such as bTB, carrion consumption by mammals can become a means of disease maintenance, with important conservation and health consequences (Gortázar et al. in press). Environmental authorities will seek conservation of wildlife, animal-health authorities will support the livestock industry and public-health authorities need to ensure the safety of all food sources destined for human consumption. These goals are all put at risk by the presence of disease in wildlife, yet the actions required by each authority to mitigate the disease effects are likely to be different, leading to conflict.

\section{Risk factors and management options for diseases and disease-related conflicts}

The main disease-related risk factors for mammal conservation include the following: the intrinsic characteristics of metapopulation dynamics, such as stochasticity and loss of genetic variability; natural or artificial movements of hosts, vectors and pathogens; and the consequences of wildlife overabundance (Gog et al. 2002). Management options will not only depend on the status of the endangered host species and the epidemiology of the diseases considered, but also on the levels of existing conflict, which in turn depend on many factors linked with local population perceptions at a given time.

Ellingwood and Spignesi (1986) introduced the concept of cultural carrying capacity (CCC) for wildlife management. It was defined as the maximum number of a given wild species that can coexist compatibly with the local human population. The number is based on human perceptions, values, beliefs, attitudes and preferences. Despite usually being applied to wildlife overabundance causing crop damage or animalvehicle accidents, we suggest CCC, in a broad sense including not only animal density, but also their distribution and potential impact on human activities, can also be used in wildlife disease management. A clear example of how CCC could be applied is with the problem of brucellosis in bison (Bison bison) in the Yellowstone National Park. Identified in bison since 1917, brucellosis represents a major threat to the livestock industry in the areas surrounding the park in Montana, USA. If brucellosis spreads into the state herd, the brucellosis-free status they currently hold will be lost, with considerable negative commercial ramifications for the cattle industry (Bidwell 2010). Even if the overlapping of bison and cattle herds is limited to spring and involves a limited part (less than $0.5 \%$ ) of the total cattle population, the risk of a brucellosis spill-over from bison to cattle will become evident from the different CCC values given by different stakeholders. Cattle breeders are likely to push for strong bison-culling plans, whereas protectionists, who support the 'wildlife heritage', may tolerate larger bison numbers. This conflict is emblematic of a social division between the 'old west', a rural and agricultural economy, and the 'new west', an amenity service-based economy funded by tourism (McBeth and Shanahan 2004). Historical views influence opinions on this newer disease threat. Bison conservation is at risk if other stakeholders believe their population size is too high. Various idiosyncratic opinions and experiences will affect individuals' estimates of the CCC. If all the different stakeholders were consulted, the average CCC could be calculated, and the factors influencing variation in values identified. This approach would identify factors that may be improved to change the stakeholders' CCC, and this could usefully be applied to other cases of ungulate 'overabundance' causing disease risk.

One of the greatest causes of disease-related conflicts can be the human perception that wildlife diseases represent a threat to livestock health, especially during times when eradication programmes are in progress. Although this is often true, in some cases the risk is very low or negligible, and lack of knowledge in the local population leads to unnecessary conflict. For example, after the first cases of brucellosis in Alpine ibex (Capra ibex) were reported (Ferroglio et al. 1998), livestock breeders and hunting associations stressed the risk to public health posed by the infected ibex individuals. However, further research demonstrated that Alpine ibex does not infect goats and sheep, even after 70 days of strict cohabitation (Ferroglio et al. 2007). Following these results, the local population no longer considered the problem to be of great concern. This highlights the importance of research to quantify the risks and ensure that stakeholders understand what risks actually exist and how to minimise them. This approach could be very useful in efforts to change people's behaviour, for example to reduce the movement of animals or change how people keep and maintain the health of their domestic pets.

In situations where conflicts already exist, the use of a novel approach to resolve the situation may encourage a greater level of agreement from opposed stakeholders. For example, the development and use of a fox oral vaccination for the control of rabies greatly helped reduce the 'old hatred' against wild carnivores, especially foxes, in areas where rabies represented a threat (Rotivel et al. 2003). Similarly, the use of an oral bait containing antihelminth drugs against Echinococcus multilocularis, a tapeworm of foxes that can also affect humans in their larval stage, greatly reduced the risks to human health and increased local acceptance of foxes (Romig et al. 2007). Demonstrating such examples of simple solutions to wildlife disease problems to stakeholders facing similar situations in other locations where conflicts could arise, may be beneficial. A proactive approach to sharing knowledge among stakeholders in this way could prevent emerging conflicts before they become established.

To manage wildlife diseases that threaten conservation efforts, sound scientific background knowledge of the host-parasite relationship is required. Multidisciplinary research teams are recommended for a full understanding of these relationships, utilising expertise in pathogen epidemiology and host ecology (Vicente et al. 2007). However, not all disease transmission is determined by the same risk factors, and not all risk factors can be managed. Breaking down the problem and determining the effect of each single factor (Alzaga et al. 2009), including stakeholder 
conflicts and actions, will identify those aspects of the situation that are suitable for management. Even if management options are limited or difficult, their costs and benefits must always be weighed against the results of taking no action (Wobeser 1994). Inclusion of socio-economists in conservation efforts will lead to a much greater understanding of what can be achieved, and will reduce the likelihood of conflicts emerging. Investment in informing stakeholders of the results of research and proving the levels of risk involved may prove a cost-effective way of changing stakeholders' estimates of the CCC and reducing conflicts.

Open discussion of stakeholders' views and their opinions on how the situation might be resolved may identify viable diseasecontrol options that help mitigate conflicts without negatively affecting the conservation effort. For instance, regarding the bTB problem in Riding Mountain National Park, Canada, management activities that not only reduce the frequency of elk interactions with farms, but also recognise the complex relationship that farmers have with wildlife and protected areas, were suggested to be the most effective in mitigating farmer concerns about the disease (Brook and McLachlan 2009). Indeed, good communication might be the best way to identify new threats to conservation before they become established conflicts. In Sweden, involving stakeholders in the study of reindeer (Rangifer tarandus) herding and other land uses through the use of participatory GIS with all land managers has increased communication and reduced conflicts (Sandström et al. 2003).

In conclusion, it is highly important that stakeholder concerns are incorporated into conservation efforts from the beginning, and that consultation occurs to estimate the CCC for the disease or disease-host species in the area. Informing stakeholders of the risks involved and reporting to them the results of research may also reduce conflicts. Multidisciplinary research may uncover effective management strategies by combining the results of consultations with stakeholders with ecological and epidemiological knowledge. Greater emphasis on engagement with stakeholders at all stages of a conservation strategy is likely to be a cost-effective way to increase the chances of survival of many endangered species threatened by conflicts over disease.

\section{Acknowledgements}

This text summarises an invited presentation at the Mammal Society Symposium on 'Human-wildlife conflict resolution' in London, 2009. CG acknowledges additional support from Plan Nacional AGL2008-3875 and EU FP7 TB-STEP grant 212414. PA is currently holding a Juan de la Cierva research contract awarded by the Ministerio de Ciencia e Innovación, Fondo Social Europeo. CEL is jointly funded by the NERC and ESRC research councils.

\section{References}

Alzaga, V., Tizzani, P., Acevedo, P., Ruiz-Fons, F., Vicente, J., and Gortázar, C. (2009). Deviance partitioning of host factors affecting parasitization in the European brown hare (Lepus europaeus). Naturwissenschaften 96, 1157-1168. doi:10.1007/s00114-009-0577-y

Angulo, E., and Cooke, B. D. (2002). First synthesize new viruses then regulate their release? The case of the wild rabbit. Molecular Ecology 11, 2703-2709. doi:10.1046/j.1365-294X.2002.01635.x
Artois, M., Bengis, R., Delahay, R. J., Duchêne, M. J., Duff, J. P., Ferroglio, E., Gortazar, C., Hutchings, M. R., Kock, R. A., Leighton, F. A., Mörner, T., and Smith, G. C. (2009) Wildlife disease surveillance and monitoring. In 'Management of Disease in Wild Mammals'. (Eds R. J. Delahay, G. C. Smith and M. R. Hutchings.) pp. 187-213. (Springer: New York.)

Bárcena, J., Morales, M., and Vázquez, B. (2000). Horizontal transmissible protection against myxomatosis and rabbit hemorrhagic disease by using a recombinant myxoma virus. Journal of Virology 74, 1114-1123. doi:10.1128/JVI.74.3.1114-1123.2000

Bennett, R. M., and Willis, K. G. (2008). Public values for badgers, bovine TB reduction and management strategies. Journal of Environmental Planning and Management 51, 511-523. doi:10.1080/09640560802116996

Bennett, R. M., Cooke, R. J., and Ijpelaar, A. C. E. (2005). Economic assessment of bovine tuberculosis and alternative policies. Cattle Practitioner 13, 235-238.

Bidwell, D. (2010). Bison, boundaries and brucellosis: risk perception and political ecology at Yellowstone. Society \& Natural Resources 23, 14-30. doi:10.1080/08941920802132575

Brook, R. K., and McLachlan, S. M. (2009). Transdisciplinary habitat models for elk and cattle as a proxy for bovine tuberculosis transmission risk. Preventive Veterinary Medicine 91, 197-208. doi:10.1016/j.prevetmed. 2009.05.021

Caughley, G. (1981). Overpopulation. In 'Problems in Management of Locally Abundant Wild Mammals'. (Eds P. A. Jewell, S. Holt and D. Hart.) pp. 7-19. (Academic: New York.)

Côté, S. D., Rooney, T. P., Tremblay, J. P., Dussault, C., and Waller, D. M. (2004). Ecological impacts of deer overabundance. Annual Review of Ecology Evolution and Systematics 35, 113-147. doi:10.1146/annurev. ecolsys.35.021103.105725

Cunningham, M. W., Brown, M. A., Shindle, D. B., Terrell, S. P., Hayes, K. A., Ferree, B. C., McBride, R. T., Blankenship, E. L., Jansen, D., Citino, S. B., Roelke, M. E., Kiltie, R. A., Troyer, J. L., and O’Brien, S. J. (2008). Epizootiology and management of feline leukemia virus in the Florida puma. Journal of Wildlife Diseases 44, 537-552.

Delibes-Mateos, M., Redpath, S. M., Angulo, E., Ferreras, P., and Villafuerte, R. (2007). Rabbits as a keystone species in southern Europe. Biological Conservation 137, 149-156. doi:10.1016/j.biocon.2007.01.024

Delibes-Mateos, M., Delibes, M., Ferreras, P., and Villafuerte, R. (2008). Key role of European rabbits in the conservation of the Western Mediterranean basin hotspot. Conservation Biology 22, 1106-1117. doi:10.1111/j.1523-1739.2008.00993.x

Donázar, J. A., Margalida, A., Carrete, M., and Sánchez-Zapata, J. A. (2009). Too sanitary for vultures. Science 326, 664. doi:10.1126/science.326 $664 a$

Donnelly, C. A., Woodroffe, R., Cox, D. R., Bourne, J., Gettinby, G., Le Fevre, A. M., McInerney, J. P., and Morrison, W. I. (2003). Impact of localized badger culling on tuberculosis incidence in British cattle. Nature 426, 834-837. doi:10.1038/nature02192

Ellingwood, M. R., and Spignesi, J. P. (1986). Management of an urban deer herd and the concept of cultural carrying capacity. Transitions of the Northeast Deer Technical Committee 22, 42-45.

Fenner, F., and Fantini, B. (1999). 'Biological Control of Vertebrate Pests: the History of Myxomatosis, and Experiment in Evolution.' (CABI Publishing: Wallingford, UK.)

Ferroglio, E., Tolari, F., Bollo, E., and Bassano, B. (1998). First isolation of Brucella melitensis from Alpine ibex. Journal of Wildlife Diseases 34, 400-402.

Ferroglio, E., Gennero, M. S., Pasino, M., Bergagna, S., Dondo, A., Grattarola, C., Rondoletti, M., and Bassano, B. (2007). Cohabitation of a Brucella melitensis infected Alpine ibex (Capra ibex) with domestic small ruminants in an enclosure in Gran Paradiso National Park, in western Italian Alps. European Journal of Wildlife Research 53, 158-160. doi:10.1007/s10344-006-0077-8 
Fisher, D. O., Blomberg, S. P., and Owens, I. P. F. (2003). Extrinsic versus intrinsic factors in the decline and extinction of Australian marsupials. Proceedings. Biological Sciences 270, 1801-1808. doi:10.1098/ rspb.2003.2447

Garrote, G., Perez de Ayala, R., Pereira, P., Robles, F., Guzman, N., García, F. J., Iglesias, M. C., Hervás, J., Fajardo, I., Simón, M., and Barroso, J. L. (in press). Estimation of the Iberian lynx (Lynx pardinus) population in the Doñana area, SW Spain, using capture-recapture analysis of cameratrapping data. European Journal of Wildlife Research. doi:10.1007/ s10344-010-0440-7

Gog, J., Woodroffe, R., and Swinton, J. (2002). Disease in endangered metapopulations: the importance of alternative hosts. Proceedings of the Royal Society of London. Series B. Biological Sciences 269, 671-676. doi:10.1098/rspb.2001.1667

Gortázar, C., Acevedo, P., Ruiz-Fons, F., and Vicente, J. (2006). Disease risks and overabundance of game species. European Journal of Wildlife Research 52, 81-87. doi:10.1007/s10344-005-0022-2

Gortázar, C., Torres, M. J., Vicente, J., Acevedo, P., Reglero, M., de la Fuente, J., Negro, J. J., and Aznar, J. (2008). Bovine tuberculosis in Doñana Biosphere Reserve: the role of wild ungulates as disease reservoirs in the last Iberian lynx strongholds. PLOS ONE 3, e2776. doi:10.1371/journal. pone. 0002776

Gortázar, C., Vicente, J., Boadella, M., Ballesteros, C., Galindo, R. C., Garrido, J., Aranaz, A., and de la Fuente, J. (in press). Progress in the control of bovine tuberculosis in Spanish wildlife. Veterinary Microbiology.

Griffin, J. M., Williams, D. H., Kelly, G. E., Clegg, T. A., O’Boyle, I., Collins, J. D., and More, S. J. (2005). The impact of badger removal on the control of tuberculosis in cattle herds in Ireland. Preventive Veterinary Medicine 67, 237-266. doi:10.1016/j.prevetmed.2004.10.009

Grilo, C., Moco, G., Candido, A. T., Alexandre, A. S., and Petrucci-Fonseca, F. (2002). Challenges for the recovery of the Iberian wolf in the Douro river south region. Revista la Biologica 20, 121-133.

Gurevitch, J., and Padilla, D. K. (2004). Are invasive species a major cause of extinctions? Trends in Ecology \& Evolution 19, 470-474. doi:10.1016/ j.tree.2004.07.005

Gylys, L., Chomel, B. B., and Gardner, I. A. (1998). Epidemiological surveillance of rabies in Lithuania from 1986 to 1996. Revue Scientifique et Technique Office International des Epizooties 17, 691-698.

Hanson, D. A., Britten, H. B., Restani, M., and Washburn, L. R. (2007). High prevalence of Yersinia pestis in black-tailed prairie dog colonies during an apparent enzootic phase of sylvatic plague. Conservation Genetics $\mathbf{8}$, 789-795. doi:10.1007/s10592-006-9226-6

Haydon, D. T., Randall, D. A., Matthews, L., Knobel, D. L., Tallents, L. A., Gravenor, M. B., Williams, S. D., Pollinger, J. P., Cleaveland, S., Woolhouse, M. E. J., Sillero-Zubiri, C., Marino, J., Macdonald, D. W., and Laurenson, M. K. (2006). Low-coverage vaccination strategies for the conservation of endangered species. Nature 443, 692-695. doi:10.1038/ nature 05177

Henzell, R. P., Cooke, B. D., and Mutze, G. J. (2008). The future of biological control of pest populations of European rabbits Oryctolagus cuniculus. Wildlife Research 35, 633-650. doi:10.1071/WR06164

Jenkins, H. E., Woodroffe, R., and Donnelly, C. A. (2010). The duration of the effects of repeated widespread badger culling on cattle tuberculosis following the cessation of culling. PLOS ONE 5(2), e9090. doi:10.1371/ journal.pone.0009090

Knobel, D. L., Fooks, A. R., Brookes, S. M., Randall, D. A., Williams, S. D., Argaw, K., Shiferaw, F., Tallents, L. A., and Laurenson, M. K. (2008). Trapping and vaccination of endangered Ethiopian wolves to control an outbreak of rabies. Journal of Applied Ecology 45, 109-116. doi:10.1111/ j.1365-2664.2007.01387.x

Lees, A. C., and Bell, D. J. (2008). A conservation paradox for the $21 \mathrm{st}$ century: the European wild rabbit Oryctolagus cuniculus, an invasive alien and an endangered native species. Mammal Review 38, 304-320. doi:10.1111/j.1365-2907.2008.00116.x
Lemus, J. A., Blanco, G., Grande, J., Arroyo, B., García-Montijano, M., and Martínez, F. (2008). Antibiotics threaten wildlife: circulating quinolone residues and disease in avian scavengers. PLOS ONE 3, e1444. doi:10.1371/journal.pone. 0001444

Logiudice, K. (2003). Trophically transmitted parasites and the conservation of small populations: raccoon roundworm and the imperiled allegheny woodrat. Conservation Biology 17, 258-266. doi:10.1046/j.1523-1739. 2003.01293.x

López, G., López-Parra, M., Fernández, L., Martínez-Granados, C., Martínez, F., Meli, M. L., Gil-Sánchez, J. M., Viqueira, N., Díaz-Portero, M. A., Cadenas, R., Lutz, H., Vargas, A., and Simón, M. A. (2009). Management measures to control a feline leukemia virus outbreak in the endangered Iberian lynx. Animal Conservation 12, 173-182. doi:10.1111/j.14691795.2009.00241.x

Mateo-Tomás, P., and Olea, P. P. (2010). When hunting benefits raptors: a case study of game species and vultures. European Journal of Wildlife Research 56, 519-528. doi:10.1007/s10344-009-0341-9

McBeth, M. K., and Shanahan, E. A. (2004). Public opinion for sale: the role of policy marketers in Greater Yellowstone policy conflict. Policy Sciences 37, 319-338. doi:10.1007/s11077-005-8876-4

Millán, J., Naranjo, V., Rodriguez, A., Perez de la Lastra, J. M., Mangold, A. J., and de la Fuente, J. (2007). Prevalence of infection and 18S rRNA gene sequences of Cytauxzoon species in Iberian lynx (Lynx pardinus) in Spain. Parasitology 134, 995-1001. doi:10.1017/S003118200700248X

Millán, J., Candela, M. G., Palomares, F., Cubero, M. J., Rodriguez, A., Barral, M., de la Fuente, J., Almeria, S., and Leon-Vizcaino, L. (2009). Disease threats to the endangered Iberian lynx (Lynx pardinus). Veterinary Journal 182, 114-124. doi:10.1016/j.tvj1.2008.04.005

Moreno, S., Beltrán, J. F., Cotilla, I., Kuffner, B., Laffite, R., Jordán, G., Ayala, J., Quintero, C., Jiménez, A., Castro, F., Cabezas, S., and Villafuerte, R. (2007). Long-term decline of the European wild rabbit (Oryctolagus cuniculus) in south-western Spain. Wildlife Research 34, 652-658.

Pope, L. C., Butlin, R. K., Wilson, G. J., Woodroffe, R., Erven, K., Conyers, C. M., Franklin, T., Delahay, R. J., Cheeseman, C. L., and Burke, T. (2007). Genetic evidence that culling increases badger movement: implications for the spread of bovine tuberculosis. Molecular Ecology 16, 4919-4929. doi:10.1111/j.1365-294X.2007.03553.x

Real, R., Barbosa, A. M., Rodriguez, A., Garcia, F. J., Vargas, J. M., Palomo, L. J., and Delibes, M. (2009). Conservation biogeography of ecologically interacting species: the case of the Iberian lynx and the European rabbit. Diversity \& Distributions 15, 390-400. doi:10.1111/j.1472-4642.2008. 00546.x

Reglero, M. M., Monsalve-González, L., Taggart, M. A., and Mateo, R. (2008). Transfer of metals to plants and red deer in an old lead mining area in Spain. The Science of the Total Environment 406, 287-297. doi:10.1016/j.scitotenv.2008.06.001

Rodríguez, A. (2007). Lynx pardinus Temminck 1827. In 'Atlas y Libro Rojo de los Mamíferos Terrestres de España'. (Eds L. J. Palomo, J. Gisbert and J. C. Blanco.) pp. 342-344. (Dirección General para la Biodiversidad SECEM-SECEMU: Madrid.)

Roelke, M. E., Johnson, W. E., Millan, J., Palomares, F., Revilla, E., Rodriguez, A., Calzada, J., Ferreras, P., Leon-Vizcaino, L., Delibes, M., and O'Brien, S. J. (2008). Exposure to disease agents in the endangered Iberian lynx (Lynx pardinus). European Journal of Wildlife Research 54, 171-178. doi:10.1007/s10344-007-0122-2

Roelke-Parker, M. E., Munson, L., Packer, C., Kock, R., Cleaveland, S., Carpenter, M., Obrien, S. J., Pospischil, A., Hofmann-Lehmann, R., Lutz, H., Mwamengele, G. L. M., Mgasa, M. N., Machange, G. A., Summers, B. A., and Appel, M. J. G. (1996). A canine distemper virus epidemic in Serengeti lions (Panthera leo). Nature 379, 441-445. doi:10.1038/ $379441 \mathrm{a} 0$

Romig, T., Dinkel, A., Merli, M., Thoma, D., Will, R., Mackenstedt, U., Lucius, R., and Versita, W. (2007). Impact of praziquantel baiting on intestinal helminths of foxes in southwestern Germany. Helminthologia 44, 137-144. doi:10.2478/s11687-007-0021-9 
Rondinini, C., and Boitani, L. (2007). Systematic conservation planning and the cost of tackling conservation conflicts with large carnivores in Italy. Conservation Biology 21, 1455-1462. doi:10.1111/j.1523-1739.2007. 00834.X

Rotivel, Y., Goudal, M., and Simons de Fanti, A. (2003). Human rabies prophylactis: the French experience. Vaccine 21, 710-715. doi:10.1016/ S0264-410X(02)00586-8

Ruiz-Fons, F., Segalés, J., and Gortázar, C. (2008). A review of viral diseases of the European wild boar: effects of population dynamics and reservoir role. Veterinary Journal 176, 158-169. doi:10.1016/j.tvj1.2007.02.017

Rushton, S. P., Lurz, P. W. W., Gurnell, J., Nettleton, P., Bruemmer, C., Shirley, M. D. F., and Sainsbury, A. W. (2006). Disease threats posed by alien species: the role of a poxvirus in the decline of the native red squirrel in Britain. Epidemiology and Infection 134, 521-533. doi:10.1017/ S0950268805005303

Sandström, P., Pahlén, T. G., Edenius, L., Tømmervik, H., Hagner, O., Hemberg, L., Olsson, H., Baer, K., Stenlund, T., Brandt, L. G., and Egberth, M. (2003). Conflict resolution by participatory management: remote sensing and GIS as tools for communicating land-use needs for reindeer herding in northern Sweden. Ambio 32, 557-567.

Saunders, G., Cooke, B., McColl, K., Shine, R., and Peacock, T. (2010). Modern approaches for the biological control of vertebrate pests: an Australian perspective. Biological Control 52, 288-295. doi:10.1016/ j.biocontrol.2009.06.014

Smith, K. F., Acevedo-Whitehouse, K., and Pedersen, A. B. (2009). The role of infectious diseases in biological conservation. Animal Conservation 12, 1-12. doi:10.1111/j.1469-1795.2008.00228.x

Taggart, M. A., Cuthbert, R., Das, D., Sashikumar, C., Pain, D. J., Green, R. E., Feltrer, Y., Shultz, S., Cunningham, A. A., and Meharg, A. A. (2007). Diclofenac disposition in Indian cow and goat with reference to Gyps vulture population declines. Environmental Pollution 147, 60-65. doi:10.1016/j.envpol.2006.08.017

Thorne, E. T., and Williams, E. S. (1988). Disease and endangered species: the black-footed ferret as a recent example. Conservation Biology 2, 66-74. doi:10.1111/j.1523-1739.1988.tb00336.x
Tyndale-Biscoe, C. H. (1991). Fertility control in wildlife. Reproduction, Fertility and Development 3, 339-343. doi:10.1071/RD9910339

Vicente, J., Delahay, R. J., Walker, N., and Cheeseman, C. L. (2007). Social organisation and movement influence the incidence of bovine tuberculosis in an undisturbed high density badger (Meles meles) population. Journal of Animal Ecology 76, 348-360. doi:10.1111/ j.1365-2656.2006.01199.x

von Arx, M., and Breitenmoser-Wursten, C. (2008). Lynx pardinus. In 'IUCN 2009. IUCN Red List of Threatened Species. Version 2009.2'. Available at www.iucnredlist.org [accessed June 2010].

Vos, A. (2003). Oral vaccination against rabies and the behavioural ecology of the red fox (Vulpes vulpes). Journal of Veterinary Medicine Series BInfectious Diseases and Veterinary Public Health 50, 477-483.

Williams, D., Acevedo, P., Gortázar, C., Escudero, M. A., Labarta, J. L., Marco, J., and Villafuerte, R. (2007). Hunting for answers: rabbit (Oryctolagus cuniculus) population trends in northeastern Spain. European Journal of Wildlife Research 53, 19-28. doi:10.1007/ s10344-006-0056-0

Wobeser, G. A. (1994). 'Investigation and Management of Diseases in Wild Animals.' (Plenum Press: London.)

Woodford, M., and Rossiter, P. B. (1993). Disease risks associated with wildlife translocation projects. Revue Scientifique et Technique Office International des Epizooties 12, 115-135.

Woodroffe, R., Donnelly, C. A., Cox, D. R., Bourne, F. J., Cheeseman, C. L., Delahay, R. J., Gettinby, G., McInerney, J. P., and Morrison, W. I. (2006). Effects of culling on badger Meles meles spatial organisation: implications for the control of bovine tuberculosis. Journal of Applied Ecology 43, 1-10. doi:10.1111/j.1365-2664.2005.01144.x

Manuscript received 19 February 2010, accepted 14 October 2010 